\title{
Delays in the Pre-Construction Phase of State Sector Building Projects
}

\author{
D A R Dolage and P W S D Perera
}

\begin{abstract}
This paper investigates the many causes of delays in the pre-construction phase of State Sector Building Projects. The investigation was done through a questionnaire based survey that involved Clients, Consultants and Contractors to evaluate the causes of delays. The technique of Relative Importance Index was adopted to rank the causes of delays in a descending order. Based on this evaluation the causes of delays were identified and ranked, and two remedial measures were developed. Firstly, a process diagram for the pre-construction phase was designed in order to establish the systematic process and to represent useful inputs and outputs at various stages of the process. Secondly, a checklist was formulated in an effort to ensure that important actions are taken at the correct stages to minimise the opportunity for delays. Also, the study proposes suitable additions/amendments to the 'Form of Agreement', an ICTAD publication, and recommends to make the use of these remedial measures mandatory.
\end{abstract}

Key words: Pre-Construction Phase, Construction Industry, Causes of Delays

\section{Introduction}

The problem of delays in the pre-construction phase in the construction industry is a common phenomenon. The pre-construction phase can be further divided into ten sub phases namely, consultancy agreement, preliminary project brief, final project brief, pre-feasibility studies, detailed feasibility studies, schematic designs, architectural designs, structural and service design, tender documents, bidding and negotiation. All these phases are in the critical path of the building procurement process and therefore the delay in each phase has a direct influence on the total project duration.

In State Sector Projects, any one person may not represent the client throughout the project. Most of the time the client may not have the full authority to make decisions. They may have to seek the Departmental and Ministerial level approvals on various issues. As a result, state sector clients are less likely to be accountable for the delays in the pre-construction phase. Instead, they are only mindful about the time allotted for the construction in the contract. In contrast, private sector clients are keen on the entire project duration in order to obtain the maximum return for the investment. Hence, they strictly monitor the pre-construction phase by adopting more flexible procedures, which facilitates quick decisions. It is observed that state sector building projects get delayed unnecessarily due to delays in decisions made by clients. A major reason for this situation is that in state sector decision making, the participation of several government officials is needed. Therefore, any study conducted to explore the causes of delays in the pre-construction phase, has to be conducted separately for the two sectors. In the current economic downturn, in order to remain competitive, the lead consultants and specialist consultants operate with the minimum permanent staff and by outsourcing some of the important work. As a result of the inevitable poor coordination, the consultants can not perform the expected role. The effects of this are manifested in the construction stage in the form of delays and cost overruns.

In state sector projects, pre-construction delays that contribute to the overall delays in construction projects are often responsible for turning profitable projects into losses. These delays can be avoided or reduced, if the major causes for such delays can be identified and dealt with effectively.

The objectives of this study are;

(i) to identify major causes of delays at different stages

(ii) to assess the relative importance of these causes

Eng. D.A.R.Dolage, CEng, FIE(Sri Lanka), BSc Eng. (Moratuwa), MSc (Reading), MA (Colombo), MBA (SJP), Senior Lecturer, Department of Civil Engineering. The Open University of Sri Lanka

Eng. Captain P.W.S.D. Perera, CEng, MIE(Sri Lanka), BSc Eng. (Moratuwa), MTech (OUSL), Director Projects, Daya Constructions (Pvt) Ltd. 
(iii) to develop a process diagram and a mandatory checklist for the pre construction phase in order to minimise these delays.

This paper is organised as follows: Section 2 deals with the literature review on causes of delays in the pre-construction phase; Section 3 illustrates the methodology of research; Section 4 provides the analysis of the data and results, Section 5 presents the discussion and conclusion and Section 6 deals with recommendations.

\section{Literature Review}

The primary objective to be accomplished during pre-construction phase is to produce the information needed to complete projects on time, within the budget and to the satisfaction of the client. The pre-construction phase is usually planned for individual projects, with each one being different from the other, although there may be much in common between them, be they buildings, highways, bridges, dams or tunnels. The ICTAD publication on Scope of Consultancy Services categorises various services provided by consultants under three categories namely, the 'Basic services', 'Extra services' and 'Other services' separately, for the six types of consultancy services in order to streamline the process of consultancy services. The 'Basic services' describes the Preliminary and basic services which the consultant will normally provide; the 'Extra services describes services which could be provided by the consultant to augment the Basic services and the 'Other services describes services which are not pertaining to the particular profession, but which could be provided on special assignments by involving other relevant consultants. The six types of consultancy services are architectural, engineering consultancy, project management, quantity surveying, structural engineering, town planning and consortium (ICTAD Publication No. ICTAD/CONSULT/04, 2002). The Client Guide, another publication of ICTAD identifies five key areas for which client consideration is of paramount importance (ICTAD Publication No. ICTAD /CONSULT/02, 2002). Moreover, while the Client Guide for the Selection of Consultants enables the selection of the most suitable consultant for the project, the Form of Agreement guides the engagement of the selected consultant (ICTAD Publications No. ICTAD/CONSULT/03 and (ICTAD Publication No. ICTAD/CONSULT/01, 2002). The services provided by lead consultants vary in scope and nature depending on the project and on the requirements of the client. The lead consultant may work in collaboration with other consultants, specialist consultants, consultants nominated by the client and the client's own personnel.

As shown above, there exist a well established procedure in order to facilitate the appointment of the most suitable consultants and thereby to avert possible undesirable eventualities, which includes possible delays in the pre-construction phase. Further, over the years each consultant will have developed its own preferred practices based on its successes and failures. According to Rutter and Martin (1990), the consultants should draw on experience as well as current standards and codes of practice when evolving designs for new schemes in order to mitigate preconstruction delays. SLS ISO 9001-2000 proposes a procedure consisting of seven steps for the design and development (SLS, 2000). While its first six steps deal with aspects such as planning, inputs, outputs, review, verification, validation of design and development process, the seventh step deals with the control of design and development changes. Although the procedure enumerated here provides a useful guideline to minimise delays in the pre-construction phase, the maximum benefits cannot be derived since it provides only a broad outline for the procedure. The consultants are free to develop their own detailed version based on the broad outline procedure. Further, the ICTAD publications on consultancy services do not make any reference to the requirement of consultants having to obtain ISO certifications such as SLS ISO 90012000.

Jayawardane and Pandita (2003) conducted an empirical study on 'Understanding and Mitigating the Factors Affecting Construction Delays' within the Sri Lankan construction industry. This study identified the factors affecting construction delays, quantifies the importance of the identified delay factors, and makes recommendations in order to minimise delays during construction. Numerous authors including Sweis et al. (2008), Sambasivan and Soon (2007), Chan and Kumaraswamy (1997) and Mansfield (1994) have studied Delays in Construction projects in various countries. Evidently, no prior studies have been carried out to investigate the delays in the pre-construction phase of the construction projects in any other country, let alone in Sri Lanka. 


\section{Methodology}

\subsection{Data collection}

As shown in the literature review, the preconstruction phase can be further sub-divided into the following ten generic phases:

\section{Consultancy agreement \\ Preliminary project brief \\ Final Project brief \\ Pre-feasibility studies \\ Detailed feasibility studies \\ Schematic designs \\ Architectural designs \\ Structural and services designs \\ Tender documents \\ Bidding and negotiating}

Prior to the distribution of the primary questionnaire, ten interviews were conducted with four consultants, three clients and three contractors to identify the factors causing the delays in the pre-construction stage, under the above mentioned eight phases. Based on the results of these interviews, the primary questionnaire was developed to assess the perceptions of consultants, architects, structural engineers and service engineers on the relative importance of causes of delays during the pre-construction phase. The questionnaire was divided into two parts. The first part sought the background information about characteristics of the respondents. The second part of the questionnaire focused on the relative importance of the causes of delays, in the pre-construction phase. A five point Likert scale ranging from 1 (not important) to 5 (extremely important) was adopted to capture the importance of the causes of delays.

The data was obtained from a large spectrum of state sector building projects of which preconstruction phase was managed by either semi government organisations or private sector organisations. A field survey was intended to cover state sector building projects of value over Rs. 10 million. Due to the possible poor response for questionnaires, 50 personally known professionals were engaged in the questionnaire survey. Although forty-two questionnaires were received, only thirty could be used, since 12 were incomplete.

\subsection{Calculation of relative importance of Factors}

Kometa et. al. (1994) adopted the Relative Importance Index (RII) method to determine the relative importance of the various causes of the delays. The same method was engaged in this study within various groups. The fivepoint scale ranged from 1 (not important) to 5 (extremely important) was used to transform into RII for each cause as follows:

$$
R I I=\frac{\sum W}{A^{*} N}
$$

where $\mathrm{W}$ is the weighting given to each factor by the respondents (ranging from 1 to 5 ), $\mathrm{A}$ is the highest weight (ie. 5 in this case), and $N$ is the total number of respondents. The RII value had a range from 0 to 1 ( 0 not inclusive), higher the value of RII, more important was the cause. The RII was used to rank the different causes. These rankings made it possible to cross-compare the relative importance of the factors as perceived by the respondents. The RII for each individual cause was used to assess the general and overall rankings of each cause of delay as well as to give an overall picture of the causes of delays in the pre-tender stage.

\section{Table 1: Characteristic of the Projects and Respondents}

\begin{tabular}{|c|c|}
\hline Characteristic & Frequency \\
\hline Number of respondents & 42 \\
\hline $\begin{array}{l}\text { Number of questionnaires } \\
\text { considered for the analysis }\end{array}$ & 30 \\
\hline \multicolumn{2}{|l|}{$\begin{array}{l}\text { Project Cost (inclusive of services) } \\
\text { in Rs. Million }\end{array}$} \\
\hline $10<$ and $<20$ & 4 \\
\hline $20<$ and $<40$ & 4 \\
\hline $40<$ and $<100$ & 12 \\
\hline $100<$ and $<200$ & 2 \\
\hline $200<$ & 8 \\
\hline \multicolumn{2}{|l|}{ Respondent's Profession } \\
\hline \multicolumn{2}{|l|}{ Consultant/Engineer } \\
\hline Semi Government & 22 \\
\hline Private Sector & 8 \\
\hline \multicolumn{2}{|l|}{ Architect } \\
\hline Semi Government & 20 \\
\hline Private Sector & 10 \\
\hline \multicolumn{2}{|l|}{ Structural Engineer } \\
\hline Semi Government & 22 \\
\hline Private Sector & 8 \\
\hline \multicolumn{2}{|l|}{ Service Consultant } \\
\hline Semi Government a deda & 22 \\
\hline Private Sector & 8 \\
\hline \multicolumn{2}{|l|}{ Contractor } \\
\hline Semi Government & 4 \\
\hline Private Sector & 14 \\
\hline Not yet selected & 12 \\
\hline
\end{tabular}




\section{Analysis of Data and Results}

The summaries of the characteristics of the projects based on which the respondents provided answers to the first part of the questionnaire and the characteristics of the respondents is presented in tabular form in Table 1.

Table 2: Ranking of Causes of Delays

\begin{tabular}{|c|c|c|c|c|c|c|c|}
\hline \multirow[t]{2}{*}{ Causes of delays } & \multicolumn{5}{|c|}{ Percentage of Respondents Scoring } & \multirow[t]{2}{*}{ RII } & \multirow[t]{2}{*}{ Rank } \\
\hline & 1 & 2 & 3 & 4 & 5 & & \\
\hline \multicolumn{8}{|l|}{ Consultancy agreement related } \\
\hline Description of scope of work & 2.3 & 4.7 & 0.0 & 27.9 & 65.1 & 0.898 & 6 \\
\hline Stipulation of penalty clauses for delays & 2.3 & 4.7 & 9.3 & 16.3 & 67.4 & 0.884 & 24 \\
\hline Inclusion of detailed programme for design process & 0.0 & 4.7 & 7.0 & 20.9 & 67.4 & 0.902 & 1 \\
\hline \multicolumn{8}{|l|}{ Client's preliminary project brief related } \\
\hline Indication of target cost & 0.0 & 2.3 & 9.3 & 41.9 & 46.5 & 0.865 & 11 \\
\hline Assessment of constraints & 0.0 & 2.3 & 14.0 & 25.6 & 58.1 & 0.879 & 4 \\
\hline \multicolumn{8}{|l|}{ Consultant's final project brief related } \\
\hline Indication of estimated cost & 2.3 & 2.3 & 16.3 & 30.2 & 48.9 & 0.842 & 7 \\
\hline Client studying the project brief & 0.0 & 7.7 & 6.9 & 31.3 & 54.1 & 0.864 & 2 \\
\hline & & & & & & & \\
\hline \multicolumn{8}{|l|}{ Pre-feasibility studies related } \\
\hline Preliminary site investigation & 2.3 & 2.3 & 16.3 & 37.2 & 41.9 & 0.828 & 17 \\
\hline Assessment of availability of services & 0.0 & 4.7 & 20.9 & 34.9 & 39.5 & 0.818 & 9 \\
\hline Preliminary environmental impact assessment & 2.3 & 4.7 & 20.9 & 32.6 & 39.5 & 0.805 & 26 \\
\hline Submission of alternative conceptual proposals & 4.7 & 0.0 & 20.9 & 39.5 & 34.9 & 0.800 & 5 \\
\hline \multicolumn{8}{|l|}{ Detailed feasibility studies related } \\
\hline Detailed site investigation & 0.0 & 9.3 & 23.3 & 32.6 & 34.8 & 0.786 & 28 \\
\hline Identification of major limitation of the site & 9.3 & 11.6 & 9.3 & 32.6 & 37.2 & 0.754 & 25 \\
\hline Approvals from statuary and local authority & 2.3 & 7.0 & 18.6 & 41.9 & 30.2 & 0.781 & 21 \\
\hline Preparation of cost estimate & 11.6 & 7.0 & 11.6 & 34.9 & 34.9 & 0.749 & 16 \\
\hline Final environmental impact assessment & 4.7 & 9.3 & 20.9 & 27.9 & 37.2 & 0.767 & 19 \\
\hline Submission of most suitable conceptual proposal & 9.3 & 14.0 & 20.9 & 27.9 & 27.9 & 0.740 & 8 \\
\hline \multirow{2}{*}{\multicolumn{8}{|c|}{ Schematic drawings related }} \\
\hline & & & & & & & \\
\hline $\begin{array}{l}\text { Preparation of schematic drawings } \\
\text { design proposal/reports }\end{array}$ & 7.0 & 11.6 & 20.9 & 30.2 & 30.3 & 0.730 & 18 \\
\hline Endorsement of service consultants & 11.6 & 9.3 & 16.3 & 30.2 & 32.6 & 0.726 & 14 \\
\hline Endorsement of client & 14.0 & 9.3 & 23.3 & 23.3 & 30.1 & 0.692 & 13 \\
\hline Realistic cost estimate & 9.3 & 16.3 & 18.6 & 25.6 & 30.2 & 0.702 & 20 \\
\hline \multicolumn{8}{|l|}{ Architectural drawings related } \\
\hline Preparation of scale model & 11.6 & 14.0 & 16.3 & 34.9 & 23.2 & 0.688 & 22 \\
\hline $\begin{array}{l}\text { Client's endorsement of architectural drawings prior } \\
\text { to structural design phase }\end{array}$ & 16.3 & 14.0 & 16.3 & 25.6 & 27.8 & 0.669 & 3 \\
\hline $\begin{array}{l}\text { Endorsement of architectural drawings by structural } \\
\text { engineer and service consultant }\end{array}$ & 16.3 & 14.0 & 14.0 & 25.6 & 30.1 & 0.678 & 23 \\
\hline \multicolumn{8}{|l|}{ Structural and service design related } \\
\hline $\begin{array}{l}\text { Concurrent preparation of structural and service } \\
\text { drawings }\end{array}$ & 16.3 & 16.3 & 18.6 & 20.9 & 27.9 & 0.656 & 10 \\
\hline Strength of design staff & 14.0 & 16.3 & 20.9 & 23.3 & 25.5 & 0.660 & 15 \\
\hline \multicolumn{8}{|l|}{ Bill of quantities $(B O Q)$ related } \\
\hline $\begin{array}{l}\text { Obtain Architectural, structural \& services } \\
\text { drawings, prior to preparation of BOQs. }\end{array}$ & 16.3 & 16.3 & 23.3 & 18.6 & 25.5 & 0.641 & 27 \\
\hline \multicolumn{8}{|l|}{ Tender documents related } \\
\hline $\begin{array}{l}\text { Scrutinise the consistency of architectural, structural } \\
\text { and services drawings and BOQs }\end{array}$ & 18.6 & 18.6 & 16.3 & 25.6 & 20.9 & 0.623 & 12 \\
\hline
\end{tabular}


The primary data collected from the second part of the questionnaire, in relation to causes of delays, was analysed. Table 2 depicts the RII which was computed for each cause in an effort to identify the most significant causes. The causes were ranked based on RII values. From this, it was possible to identify the most important factors or causes of delays. Table 2 also presents the ranking of causes of delays; while Rank 1 is the most important; Rank 28 is the least important.

\section{Discussion and Conclusion}

This section discusses the results obtained in the earlier section and proposes remedial measures by way of a process diagram and a checklist, in an effort to minimise delays. The ten most important causes of delays as shown in Table 2, in the descending order are:

(1) Inclusion of detailed programme for design process,

(2) Client studying the project brief,

(3) Client's endorsement of architectural drawings prior to structural design phase,

(4) Assessment of constraints in the client's brief,

(5) Submission of alternative conceptual proposals,

(6) Description of scope of work of consultants,

(7) Indication of estimated cost in the final brief,

(8) Submission of most suitable conceptual proposal,

(9) Assessment of availability of services,

(10) Concurrent preparation of structural and service drawings.

It can be said that these causes when not addressed and affecting the design process leads to significant delays in the design process. However, the other causes of delays, though not as significant as the former, can have effects on the expediency of the design process.

The preparation of a preliminary project brief by the client and a project brief by the consultant, can provide clear direction to subsequent activities in the project. It is also felt that the consultant should take the views of the end users at the stage of preparing the project brief. On receiving the endorsement of the client for the project brief, the consultant should submit alternate proposals through a prefeasibiltiy study. This will minimise any possibility of the Client having to require alternate designs at a later stage. The detailed feasibility study provides better insights to the alternative proposals. This enables the ranking of alternative proposals. Detailed feasibility studies should consider site investigation, statutory requirements and views of the other specialist consultants and entails submission of a report containing the evaluation of alternative proposals and recommendation of the most suitable proposal. The schematic drawing can commence after the client's approval is sought for this report. The endorsement of the client, service consultants and the owners of adjoining properties for the project proposal prior to the commencement of the detailed architectural drawings is important to alleviate pre-construction delays.

The structural and service drawings need to commence after receiving the endorsement of the client on the architectural drawing. As the next step, it is important to obtain the approval of the Local Authority before the preparation of $\mathrm{BOQ}$, specifications, draft tender documents, works programme and Engineers Estimate. Hence, in the light of these requirements, to avert pre-construction delays, the remedial proposals should be developed.

The two remedial measures proposed in the study are not only based on the first ten causes of delays but also on the other causes of delays.

The first measure accomplished in this study was to develop a process diagram to implement the systematic design process at pre-construction phase for state sector building projects. Figure 1 depicts the process diagram developed in this regard. However, in addition, a checklist can be formulated in order to make sure that important activities of the design process are not omitted. Table 3 depicts the proposed checklist that the consultants and clients should adopt during the design process to minimise delays. The process diagram was formulated in the light of causes of delays identified and their respective ranking. 


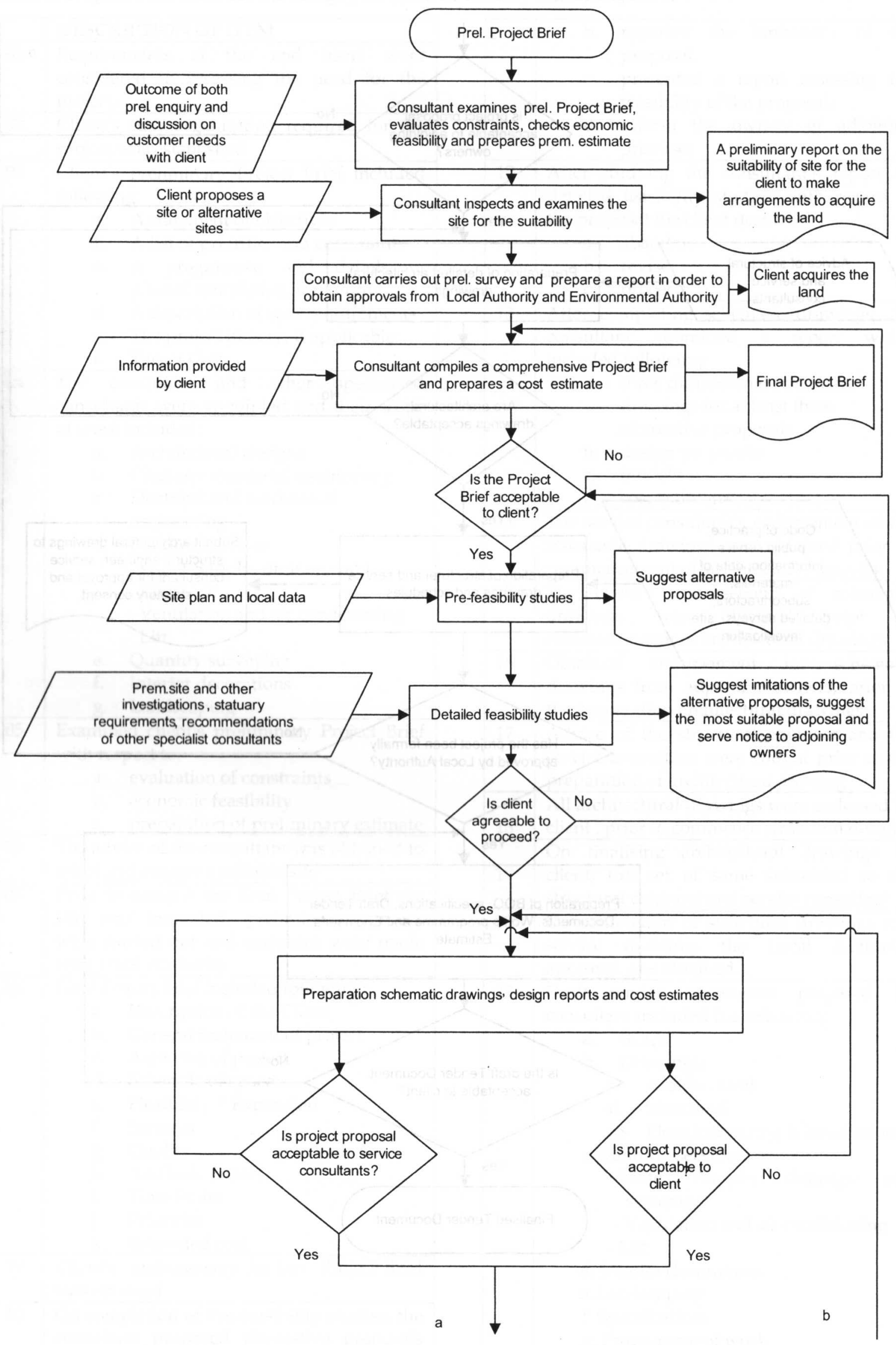




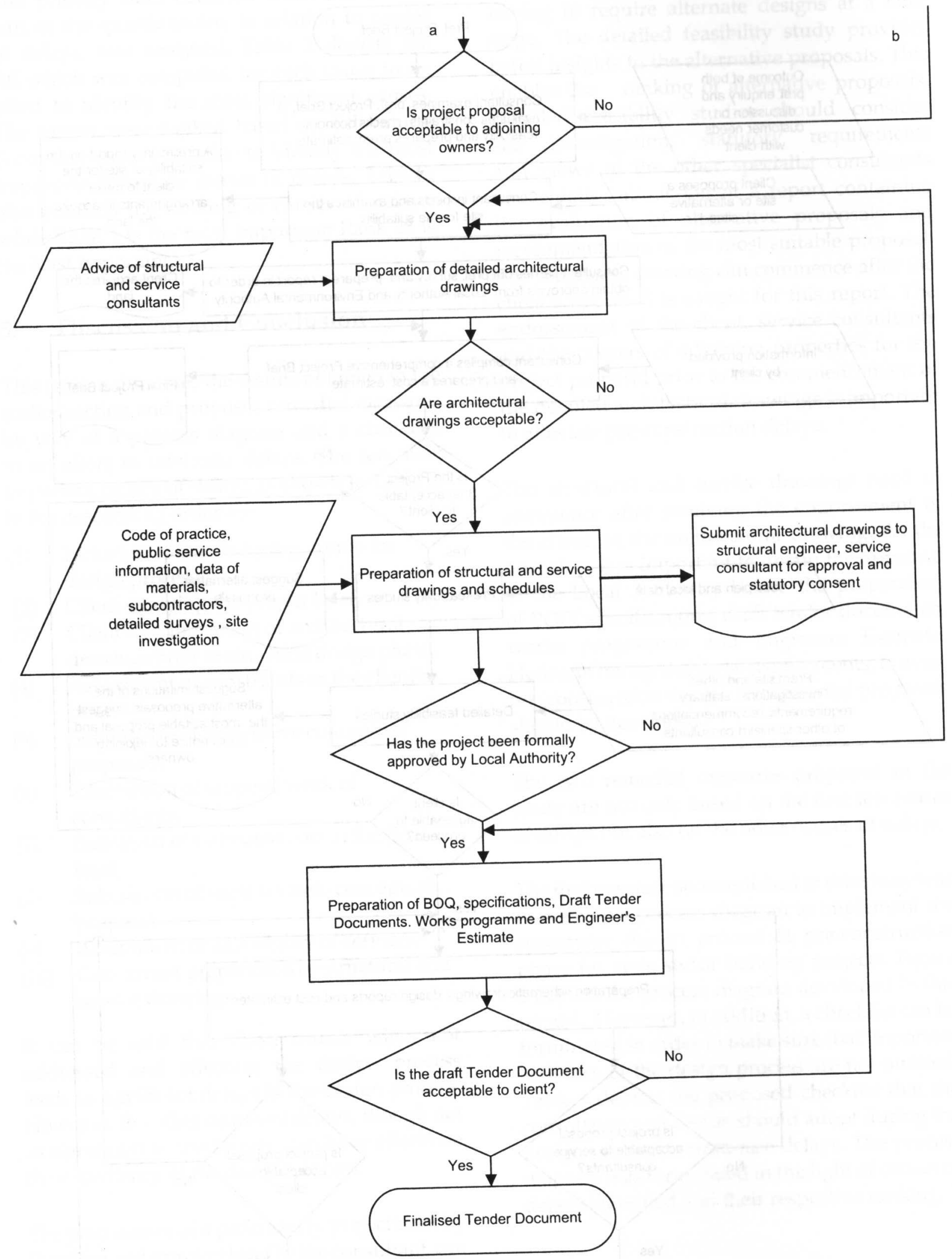

Figure 1: Process Diagram for Pre-Construction Phase of State Sector Building projects 
Table 3: Proposed checklist for the design process to be used by consultant/client

\begin{tabular}{|c|c|}
\hline & DESCRIPTION OF ITEM \\
\hline 01 & $\begin{array}{l}\text { Requirements of the end users were } \\
\text { considered in assessing the need for the } \\
\text { project. }\end{array}$ \\
\hline 02 & $\begin{array}{l}\text { Client's staff organisation required for the } \\
\text { project was established }\end{array}$ \\
\hline 03 & $\begin{array}{l}\text { Client's preliminary Project Brief included } \\
\text { following: } \\
\text { a. A statement of objectives } \\
\text { b. A list of priorities and constraints } \\
\text { c. A programme and details of } \\
\text { phased completion, if required } \\
\text { d. A description of user requirements } \\
\text { e. The project history, if applicable. } \\
\text { f. Target Cost }\end{array}$ \\
\hline 04 & $\begin{array}{l}\text { The consultant and other specialised } \\
\text { consultants were appointed and their scope } \\
\text { of work included: } \\
\text { a. Architectural designs } \\
\text { b. Civil and structural engineering } \\
\text { c. Electrical and mechanical } \\
\text { engineering } \\
\text { d. Building services } \\
\text { - Water Supply, drainage and } \\
\text { - sewerage } \\
\text { - Ventilation and air conditioning } \\
\text { e. Lift } \\
\text { f. Interior decorations } \\
\text { g. Landscaping }\end{array}$ \\
\hline 05 & $\begin{array}{l}\text { Examined client's preliminary Project Brief } \\
\text { with respect to: } \\
\text { a. evaluation of constraints } \\
\text { b. economic feasibility } \\
\text { c. preparation of preliminary estimate }\end{array}$ \\
\hline 06 & $\begin{array}{l}\text { The advice of the consultant was obtained to } \\
\text { select and acquire a suitable site }\end{array}$ \\
\hline 07 & $\begin{array}{l}\text { Prior to compile the final Project Brief the } \\
\text { site was inspected, preliminary surveys } \\
\text { were carried out and enquiries were made } \\
\text { with Local Authority }\end{array}$ \\
\hline 08 & 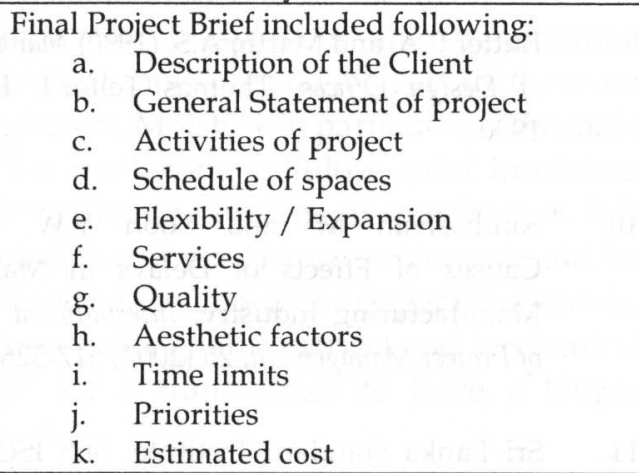 \\
\hline 09 & $\begin{array}{l}\text { Client's endorsement for the Project Brief } \\
\text { was obtained }\end{array}$ \\
\hline 10 & $\begin{array}{l}\text { On completion of Pre-feasibility studies, the } \\
\text { consultant proposed alternative proposals } \\
\text { recommending the most suitable proposal }\end{array}$ \\
\hline 11 & $\begin{array}{l}\text { On completion of detailed feasibility studies, } \\
\text { the consultant: } \\
\text { a. recommended the most suitable } \\
\text { conceptual proposal }\end{array}$ \\
\hline
\end{tabular}

\begin{tabular}{|c|c|}
\hline & $\begin{array}{l}\text { b. reported the limitations of the } \\
\text { proposal. } \\
\text { c. presented a report assessing the } \\
\text { feasibility of the proposal. } \\
\text { d. inform the owners of adjoining } \\
\text { premises }\end{array}$ \\
\hline 12 & $\begin{array}{l}\text { After studying the consultant's report on } \\
\text { detailed feasibility studies, with regard to } \\
\text { the proposal the client decided to: } \\
\text { a. abandon } \\
\text { b. revise } \\
\text { c. proceed }\end{array}$ \\
\hline 13 & $\begin{array}{l}\text { After completing schematic drawings, the } \\
\text { consultant submitted a report which } \\
\text { included following: } \\
\text { a. three dimensional schematic } \\
\text { drawings for at least three } \\
\text { alternative proposals } \\
\text { b. design proposals } \\
\text { c. models } \\
\text { d. cost estimates }\end{array}$ \\
\hline 14 & $\begin{array}{l}\text { The service consultant's endorsement of the } \\
\text { schematic drawings was obtained prior to } \\
\text { commencement of architectural drawing }\end{array}$ \\
\hline 15 & $\begin{array}{l}\text { The client's endorsement of schematic } \\
\text { drawings was obtained prior to } \\
\text { commencement of architectural drawings }\end{array}$ \\
\hline 16 & $\begin{array}{l}\text { Obtained endorsement for schematic } \\
\text { drawings from adjoining owners, prior to } \\
\text { the preparation architectural drawings }\end{array}$ \\
\hline 17 & $\begin{array}{l}\text { Advice of the structural engineer and the } \\
\text { service consultant were sought prior to the } \\
\text { preparation of architectural drawing }\end{array}$ \\
\hline 18 & $\begin{array}{l}\text { All architectural drawings were endorsed by } \\
\text { client, prior to commence structural designs }\end{array}$ \\
\hline 19 & $\begin{array}{l}\text { On finalising architectural drawings by } \\
\text { client, full set of same submitted to the } \\
\text { structural engineer and service consultant }\end{array}$ \\
\hline 20 & $\begin{array}{l}\text { On completion of structural drawings and } \\
\text { service drawing, the Local Authority } \\
\text { approval was obtained. }\end{array}$ \\
\hline 21 & $\begin{array}{l}\text { Draft tender documents prepared by } \\
\text { consultant included the following; } \\
\text { a. BOQs } \\
\text { b. Drawings; } \\
\text { i. Architectural } \\
\text { ii. Structural } \\
\text { iii. Electrical wiring \& installations } \\
\text { c. Building services } \\
\text {-Water Supply, drainage and } \\
\text { sewerage } \\
\text { - Ventilation and air conditioning } \\
\text { - Lift } \\
\text { d. Interior decorations } \\
\text { e. Landscaping } \\
\text { f. Specifications } \\
\text { g. Programme of work } \\
\text { h. Engineer's Estimate }\end{array}$ \\
\hline 22 & $\begin{array}{l}\text { After the preparation of Draft tender } \\
\text { documents, client's endorsement was } \\
\text { obtained prior to issue of Tender Documents }\end{array}$ \\
\hline
\end{tabular}




\section{References}

The responsibility of fixing a realistic time period for the pre-construction phase, rests on the consultant with the concurrence of the client. The consultant should take the proposed process diagram and the checklist into consideration in fixing the said realistic time period. Both the process diagram and the checklist has been meticulously formulated in order for any layman to comprehend easily. The insights that it gives can be used in drafting the contract between him and the consultant. Once the realistic time period for the pre-construction phase is agreed upon, the consultant should consistently follow the proposed process diagram and the checklist to make sure that the pre-construction phase can be concluded within the stipulated time period. The client too can adopt the proposed process diagram and the checklist to ensure that the consultant is adhering to the recommended procedure and thereby avoid potential delays that carries financial and other implications. The construction industry professionals consistently point out that the delays in the construction phase can be ascribed to the omission of important tasks during the design phase. Hence, it is stressed that proper adherence to the proposed measures in this study will not only pave the way to avoid delays in pre-construction phase but also helps to avert delays in the construction phase.

This study, as a furthercontribution, recommends the following amendments to the Consultancy Agreement of the ICTAD.

1. Provide a more detailed Scope of Services under the different phases of a project.

2. Provide a more detailed programme for consultancy services

3. Include a flow chart similar to the one developed in this study

4. Include a checklist to be adopted by the client/consultant

5. Include a more detailed schedule of interim payments with respect to the important milestones.

Acknowledgement: The kind assistance provided by Mr. L. Jamaldeen, General Manager, Daya Constructions (Pvt) Ltd. is gratefully appreciated.

1. Chan D.W.M. and Kumaraswamy M.M (1997) A Comparative Study of Causes of Time Overruns in Hong Kong Construction Projects, International Journal of Project Management, 1997; 15(1): 55-63

2. ICTAD, 2002, ICTAD/CONSULT/01, Form of Agreement, ICTAD, Colombo

3. ICTAD, 2002, ICTAD/CONSULT/02, Client Guide-General, ICTAD, Colombo

4. ICTAD, 2002, ICTAD/CONSULT/03, Client Guide - Selection of Consultants, ICTAD, Colombo

5. ICTAD, 2002, ICTAD/CONSULT/04, Scope of Consultancy Services, ICTAD, Colombo

6. Jayawardana A.K.W. and Pandita H.G.W (2003), Understanding and Mitigating the Factors Affecting Construction Delays, Journal of IESL, Colombo

7. Kometa, S.T., Olomolaiye P.O. and Harris F.C. (1994), Attributes of UK Construction Clients Influencing Project Consultant's Performance, Construction Management Economics, 1994, 12:433-443

8. Mansfield N.R. (1994), Causes of delay and cost overruns in Nigerian construction projects, International Journal of Project Management, 1994, 12(4): 254-260

9. Rutter P.A. and Martin A.S. (1990) Management of Design Offices, Thomas Telford, London 1990

10. Sambasivan M. and Soon Y.W. (2007), Causes of Effects of Delays in Malaysian Manufacturing Industry, International Journal of Project Management, 25 (2007) 517-526

11. Sri Lanka Standard Institute, SLS ISO 90012000

12. Sweis G., Sweis, R, Hammad A.A., Shboul, A (2008), Delays in Construction projects: The Case of Jordan, International Journal of Project Management, 26 (2008) 665-664 